\title{
Structures related to resprouting potential of two Myrtaceae species from Cerrado: morpho-anatomical and chemical studies
}

\author{
GABRIELA S. DA SILVA, ALEXANDRE FERRARO, FELIPE I.B. OGANDO, \\ CLAUDIO L. DE AGUIAR \& BEATRIZ APPEZZATO-DA-GLORIA
}

\begin{abstract}
Resprouting is a functional trait in species which occur in fire-prone ecosystems. These plants can resprout from aerial buds and by recruiting belowground bud bank using carbohydrates allocated in roots as resource. In this study, we present morpho-anatomical features and chemical composition related to the resprouting potential of two species of Eugenia L. in an area of the Cerrado (Brazilian savanna) under regeneration, after the clear-cutting of Pinus sp. with the later burning of pine needles layer. We used standard histological techniques for belowground organs analysis and aerial buds protection degree. Belowground buds in layer from soil surface down to 10 depth were counted and the chemical analyses were performed on roots. In all aerial buds, there were relevant protection traits. The belowground organ is a sobole and the number of buds in its upper portion varied from 24 to 517 between individuals of both species. Phenolic compounds, flavonoids, starch and other carbohydrates were detected in roots. The protection of aerial buds, the large number of belowground buds and the storing and protective compounds may have favored the resprouting of the species in the area.
\end{abstract}

Key words: accessory buds, bud bank, Brazilian savanna, Colleters, Eugenia dysenterica, Eugenia punicifolia.

\section{INTRODUCTION}

The ability of resprouting in response to environmental disturbances is currently recognized as a key functional trait among woody species and as basis of resilience of these plants in the environment. This ability is determined by the development, protection degree and viability of a bud bank (Clarke et al. 2013), which refers to buds in both aerial and belowground systems (Klimešová \& Klimeš 2007). The knowledge of location and protection degree of these buds is important to better understanding of the regeneration mechanisms (Vesk \& Westoby 2004). In fire-prone ecosystems, like the Brazilian
Cerrado, fire events occur frequently, and vegetation is modified as a consequence of the damage or loss of plants aboveground biomass (Clarke et al. 2013, Pereira-Júnior et al. 2014).

Resprouting from aerial buds has advantage over resprouting from buds allocated in belowground organs (Burrows \& Chisnall 2016) for providing a rapid growth in height. However, especially in woody plants, aerial buds require greater protection (Charles-Dominique et al. 2015), which can be conferred, for example, by a thick bark (Burrows \& Chisnall 2016), even though this is not an autonomous attribute (Charles-Dominique et al. 2015). In general, these buds have any of these protection traits: 
scales, stipules, base of corresponding leaf (Bell et al. 1999), epidermal appendices, such as trichomes (Burrows 2008) and colleters (Silva et al. 2012), as well as the presence of stone cells, phenolic compounds, crystals, lipids and thick cuticle (Bell et al. 1999) and can regenerate their aerial shoots after disturbances from axillary and accessory buds (Burrows 2008).

Plants responses to that disturbance are yielded by traits developed along evolutionary history (Simon et al. 2009), for example, the recruitment of a belowground bud bank (Klimešová \& Klimeš 2007), that promote persistence and aboveground biomass regeneration, restoring vegetation (Rodrigues et al. 2004, De Moraes et al. 2016, Paula et al. 2016). This bud bank can be allocated in different belowground organs, which are protected by soil, an excellent thermal insulator (Clarke et al. 2013, Pausas et al. 2018). Lignotubers, more common in ecosystems where fires of highintensity are frequent (Paula et al. 2016), exhibit a large number of buds with high protection degree as observed in Western Australian Oil Mallee (Wildy \& Pate 2002).

For resprouting after disturbance not only bud bank is necessary but also storage of carbohydrates. When the photosynthetically active tissue are absent, the storage compounds, such as glucose, fructose, sucrose, maltose, raffinose, inulin and levan type fructans, maltooligosaccharides and, more frequently, starch, are the main carbohydrates in Cerrado species, which are mobilized for resprouting after disturbance (Bombo et al. 2014, De Moraes et al. 2016, Filartiga et al. 2017a, Pausas et al. 2018). In addition to supplying energy for resprouting, some carbohydrates may offer an alternative mechanism for osmoregulation, protecting plants against low temperatures (Asega et al. 2011) and hydric deficit (Dias-Tagliacozzo et al. 2004, De Moraes et al. 2016).
Individuals from several botanical families worldwide have the ability to regenerate their photosynthetic shoots in fire-prone ecosystems (Burrows 2008, Burrows et al. 2008). However, despite the effort to understand morphoanatomical traits of plants from Cerrado, only a small number of species were analyzed in previous studies conducted on Apocynaceae (Appezzato-da-Glória \& Estelita 2000b, LopesMattos et al. 2013), Asteraceae (Appezzato-daGlória \& Cury 2011, Bombo et al. 2014), Fabaceae (Milanez \& Moraes-Dallaqua 2003), Rutaceae (Rodrigues et al. 2004, Hayashi \& Appezzato-daGlória 2009) and Smilacaceae species (Martins et al. 2010a). There is no information about resprouting mechanisms in Myrtaceae from Cerrado even if it is one of the most important botanical family in this domain (Fiaschi \& Pirani 2009) with 21 genera and approximately 344 described species (Mendonça et al. 2008). Brum et al. (2017) described sobole in Campomanesia pubescens (DC.) O. Berg (Myrtaceae) but without anatomical analyses. Due the lack of information of Brazilian Myrtaceae species regarding its adaptive aspects, mainly in the Cerrado, we evaluated morpho-anatomical traits and chemical composition related to buds protection and resprouting potential of two species of the genus Eugenia L. - Eugenia dysenterica (Mart.) DC. and E. punicifolia (Kunth).

\section{MATERIALS AND METHODS}

\section{Study site and sampling}

The study was conducted in a Cerrado region under regeneration, at the ecological station of Santa Bárbara, at Águas de Santa Bárbara municipality, São Paulo State, Brazil (2248'59"S; 49014'12"W). In 2012, Pinus sp. trees were removed after cultivation since the 1970s and the layer of pine needles was burned in 2014. Species of Eugenia dysenterica (Mart.) DC. and 
E. punicifolia (Kunth) DC. (Myrtaceae) were selected due the large number of resprouted individuals in the area after the fire event (Pilon and Durigan, personal communication). These species are perennial, native and endemic of Brazil. The habit varies between shrub and tree in E. dysenterica and, shrub and subshrub in E. punicifolia (Sobral et al. 2015). Both species occurs in Caatinga, Central Brazilian Savanna and Atlantic Rainforest phytogeographic domains (Sobral et al. 2015). The material was identified and deposited at the herbarium ESA under the numbers 140288, 140289, 140286 and 140287.

\section{Light and scanning electron microscopy analysis}

\section{Bud protection}

Three branches with apical buds and three subsequent nodal regions of three individuals of each species were fixed in FAA 50 (1:1:18; formaldehyde, glacial acetic acid and 50\% ethanol) (Johansen 1940) for 48 h, dehydrated in a graded ethanol series and included in plastic resin Leica ${ }^{\circledR}$. Longitudinal sections were obtained using a Leica 2025 rotary microtome with disposable steel knives at $7 \mu \mathrm{m}$. The sections were stained with $0.05 \%$ toluidine blue in phosphate-citrate buffer, pH 4.5 (Sakai 1973) and mounted in Entellan ${ }^{\circledR}$ synthetic resin $\left(\right.$ Merck $\left.^{\oplus}\right)$ for histological analysis. Other sections were subjected to the test with Sudan IV for total lipids (Jensen 1962), and ferric chloride for phenolic compounds (Johansen 1940). To detect cellulose, we used Calcofluor White M2R fluorochrome (Hughes \& McCully 1975) and analysis in an epifluorescence microscope using filter A (Excitation 325-375 nm, Emission 435-485 $\mathrm{nm})$.

\section{Colleters}

Five branches with apical bud and three subsequent nodal regions were collected from three individuals of each species. For the histological analyses, samples were fixed in Karnovsky solution (Karnovsky 1965) for $48 \mathrm{~h}$ and processed as described on previous topic. Part of the cross-sectional and longitudinal sections were stained with $0.05 \%$ toluidine blue in phosphate buffer and citrate pH 4.5 (Sakai 1973) and mounted in Entellan synthetic resin $\left(\right.$ Merck $\left.^{\circ}\right)$. Other sections were subjected to tests with Aniline blue black to identify the presence of protein compounds (Fisher 1968), ruthenium red for acidic mucilage (Gregory \& Baas 1989), PAS reagent for total polysaccharides (Periodic Acid-Schiff) (McManus 1948) and ferric chloride for phenolic compounds (Johansen 1940). Fresh samples were also submitted to ruthenium red reagent. For Scanning Electron Microscope (SEM), samples were fixed in Karnovsky solution (Karnovsky 1965), dehydrated in a graded ethanol series, critical-point dried using $\mathrm{CO}_{2}$ (Horridge \& Tamm 1969), mounted on aluminum stubs and coated with a thin layer (30-40 nm) of gold. The observations and eletromicrographs were made by SEM model LEO VP 435 (Zeiss, Oberkochen, Germany), operated at $20 \mathrm{kV}$, with scales directly printed.

\section{Belowground system}

Cross and longitudinal sections of different regions of the belowground organs of three individuals of both species, still fresh, were made using a sliding microtome (Leica SM2000 R) with disposable steel knives to identify the anatomical structure and carry out the following histochemical tests: Sudan IV (Jensen 1962) and Sudan Black B (Pearse 1968) for total lipids; ruthenium red for acidic mucilage (Gregory \& Baas 1989); zinc chloride iodine for starch 
grains (Strasburger 1913) and ferric chloride for phenolic compounds (Johansen 1940). Some root samples were fixed in formalin-ferrous sulphate for detection of phenolic compounds (Johansen 1940). Samples of different regions of belowground systems with buds were fixed in FAA 50 (Johansen 1940) for $48 \mathrm{~h}$ and processed as described in topic 1. The sections were stained with $0.25 \%$ safranin (Gerlach 1984, modified) and $1 \%$ alcian blue (Luque et al. 1996) and mounted in Entellan ${ }^{\oplus}$ synthetic resin (Merck ${ }^{\circledR}$ ).

For all items above, control sections were carried out as the standard procedure to confirm the histochemical tests. Digital photomicrographs were obtained using a Leica DMLB microscope and Leica DFC310 Fx camera. LAS 4.0 software (Leica) was used for image analysis. Some images were obtained with polarized light.

\section{Belowground bud bank}

The belowground bud bank was evaluated in layer from soil surface down to $10 \mathrm{~cm}$ depth where most buds are found in belowground systems in the Cerrado (Appezzato-da-Glória 2015 and literature cited). Evaluation and count was performed in belowground systems of three individuals of each species using an Opton Trinocular Stereoscopic Microscope. Digital images were obtained using a Leica DFC295 camera coupled to a Leica M205 C Stereoscopic Microscope. After counting, samples with buds were separated for the anatomical studies described above.

\section{Chemical analyses of roots}

Root samples from three individuals of each species were sectioned with a microtome and milled. The samples were dissolved in ultrapure water and vacuum-filtered in cellulose nitrate Millipore membrane with $0.45 \mu \mathrm{m}$ pore diameter. The filtrate was treated with an aluminum-based bleaching mixture to reduce influence of pigments in total carbohydrate quantification. Total carbohydrate contents were analyzed by the phenol-sulphuric method (Dubois et al. 1956). The curve was made with glucose as standard and the results expressed as $g$ of carbohydrate per $100 \mathrm{~g}$ of roots.

Then $5 \mathrm{~g}$ of the milled samples were extracted in ethanol using Sohxlet apparatus (Ferraz et al. 2000). Total phenolics and flavonoids were quantified from the ethanolic extracts.

The total phenolics were determined by mixing $100 \mu \mathrm{L}$ of the ethanolic extract of samples with $900 \mu \mathrm{L}$ of ultrapure water. Then, we added $0.5 \mathrm{~mL}$ of Folin-Ciocalteu reagent diluted at 1:10 (v/v) in ultrapure water. After $40 \mathrm{~min}, 2.5 \mathrm{~mL}$ of $4 \%$ $\mathrm{Na}_{2} \mathrm{CO}_{3}(\mathrm{~m} / \mathrm{v})$ was added and the readings were made in UV-visible spectrophotometer at 725 $\mathrm{nm}$. The results were expressed as micrograms of tannic acid equivalent (TAE) per $100 \mathrm{~g}$ of roots.

Total flavonoids were determined using a solution with $0.5 \mathrm{~mL}$ of ethanolic extract, $4.3 \mathrm{~mL}$ of $80 \%$ ethanol $(\mathrm{v} / \mathrm{v}), 0.1 \mathrm{~mL}$ of $10 \% \mathrm{Al}\left(\mathrm{NO}_{3}\right)_{3}(\mathrm{~m} / \mathrm{v})$ and $0.1 \mathrm{~mL}$ potassium acetate $\left(1 \mathrm{~mol} \mathrm{~L}^{-1}\right)$. After 40 min at rest at room temperature, absorbance was read in UV-visible spectrophotometer at 415 $\mathrm{nm}$ (Park et al., 1995). The results were exp ressed as micrograms of rutin equivalent by 100 grams of roots.

All analyses were carried out in triplicate and the results were submitted to the test ( $p<$ 0.05 and $p<0.01$ ) through the statistical package Assistat.

\section{RESULTS}

\section{Bud Protection}

In both E. dysenterica and E. punicifolia, besides the apical bud of the branches (Figs. 1a, b) in the three subsequent nodal regions above the axillary bud (Figs. 1C, d), an accessory bud occurs (Figs. 1e, f, arrows). In all the aerial buds, colleters 

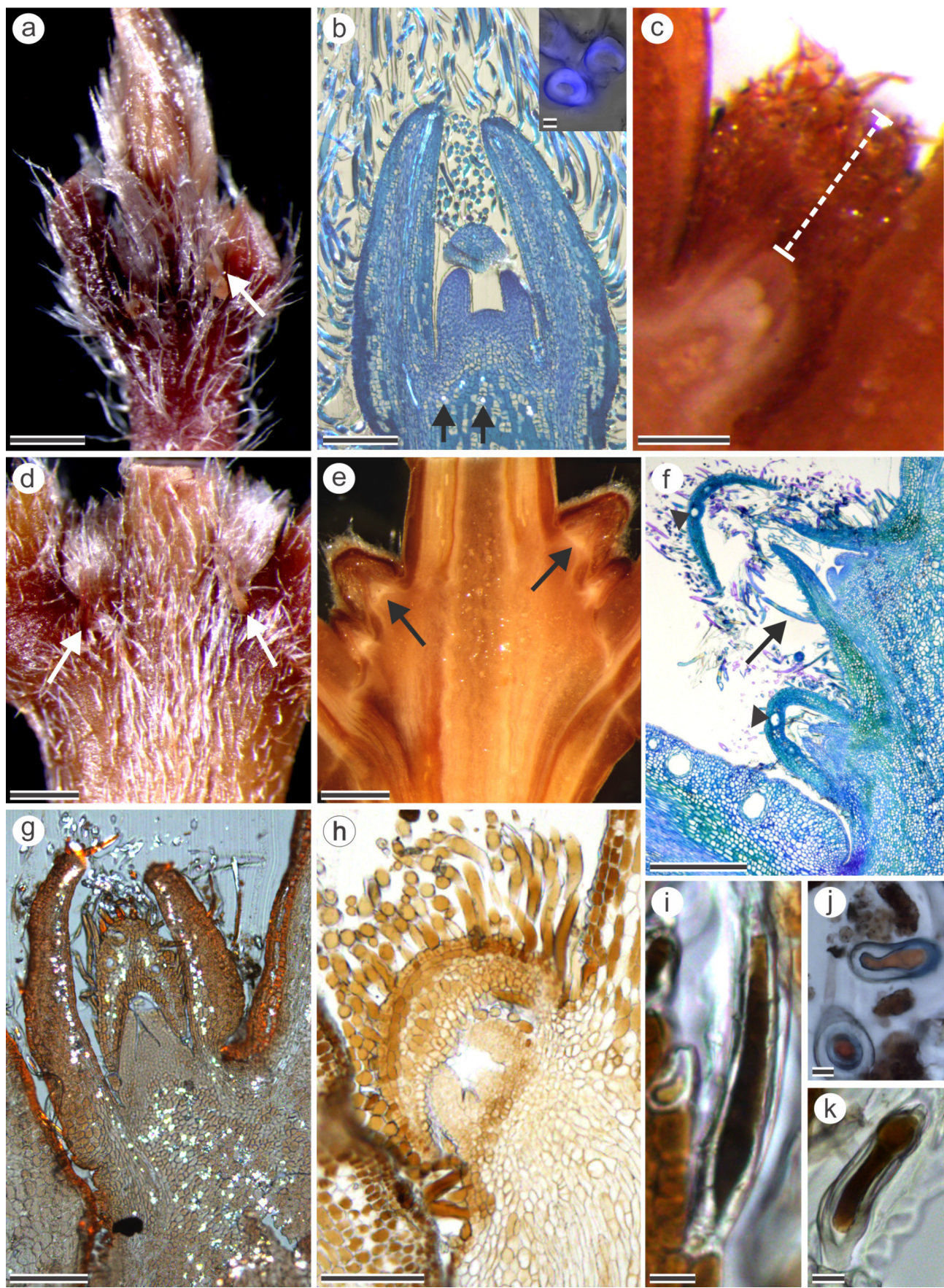

Figure 1 - Aerial buds of Eugenia dysenterica (a, c, d-g) and E. punicifolia (b, h-k).

Longitudinal sections (b, c, e-i). Analysis under polarized light (b and g). (a) Terminal and axillary buds protected by dense pubescence. Note the colleter (arrow). (b) Bud with nonglandular birefringent trichomes and crystals (arrows). In the inset, wall of non-glandular trichomes stained with Calcofluor White. (c) Dense pubescence (dashed) covering the axillary bud. (d) Nodal region with lateral colleters (arrows). (e-f) Accessory buds (arrows) and axillary buds with oil cavities (f, arrow heads). (g) Cuticle stained with Sudan IV and crystals in the axillary bud. (h-k) Phenolic compounds evidenced by ferric chloride in the axillary bud ( $h$ ) and in the non-glandular trichomes (i-k). Bars: $a, d, e=1 \mathrm{~mm} ; f=500 \mu \mathrm{m} ; \mathrm{b}$, $c, \mathbf{g}, \mathbf{h}=200 \mu \mathrm{m} ; \mathrm{i}, \mathbf{k}=20 \mu \mathrm{m}$ and $\mathbf{j}$, inset $=5 \mu \mathrm{m}$. 
occur (Figs. 1a, d, arrows). For description see next topic. The shoot apical meristem (SAM) is protected by leaf primordia with many unicellular non-glandular trichomes that also occur in young stem extension around the buds (Figs. 1a-k). These trichomes are whitish and have parietal thickening in cellulose (Fig. 1b, inset) and phenolic compounds may accumulate (Figs. $1 \mathrm{~h}-\mathrm{k}$ ). In the well-developed leaf primordia, the epidermal cells are covered by a thickened cuticle (Fig. 1g). Phenol accumulation was also observed in other epidermal and subepidermal cells, mainly, those faced to the abaxial surface of leaf primordia (Fig. 1h). There are oil cavities in the subepidermal cells (Fig. 1f). In the mesophyll, there are crystal idioblasts (Fig. 1g) and others that accumulate phenolics (Fig. 1h). The crystals also occur in buds below the SAM (Fig. 1g).

\section{Colleters}

In both species, colleters are already present in shoot apices occupying the lateral side and intrapetiolar position (Figs. 2a-e). The number and size vary; however, the shape is constant. There is only one colleter inserted on the lateral sides of the leaf primordia at the nodal region (Figs. 2a, b). Generally, there are six colleters in intrapetiolar position (Figs. 2c, d). Sizes range from 407 to $780 \mu \mathrm{m}$ and the circular diameter (Figs. 2e, f) is smaller at the apex than at the base (Fig. 2d). Some colleters are short-pedunculate, where non-secretory cells occur at the base (Fig. $2 \mathrm{~g}$ ) and other are sessile.

In both Eugenia analyzed species, the colleters are emergences that originate on the adaxial face of leaf primordia from divisions of protoderm and ground meristem cells (Figs. 2e, f). There is no participation of the procambium; therefore, the colleters are not vascularized. In secretory phase, the colleters are translucent (Fig. 2d) and constitute an elongated axis of parenchyma cells coated by epidermis of non-palisade cells (Fig. 2g) covered by a thin cuticle.

The sticky secretion (Figs. $2 \mathrm{~h}, \mathrm{i}$ ) reacts positively to PAS reagent(Figs. 2j, k) and ruthenium red (Figs. 2l-n) confirming its mucilaginous nature. The reaction with Aniline blue black was negative. The secretion accumulates in the cytosol and in the large intercellular spaces of parenchyma (Figs. 2j, k, arrows). The secretion is eliminated between epidermis cells (Fig. 2k, arrowheads) at the apex (Fig. 2l), along the axis (Fig. 2m, arrow) and at the base (Fig. 2n), where it accumulates on the axillary bud (Figs. 2c-m, arrow). The senescence starts at the colleter apex with the collapse of cells (Fig. 2j, inset), which begin to accumulate phenolic compounds after secretion (datum not shown). In some samples, there was the presence of bacteria associated with the secretion released by these structures (Fig. 2i).

\section{Belowground Bud Bank}

The number of buds in the first $10 \mathrm{~cm}$ beneath soil level varied between individuals of the same species for both E. dysenterica (Fig. 3a) (162, 253, 517) and E. punicifolia (Fig. 3e) (24, 40, 109). The variation was due to the number of branches of the belowground structures. These branches are stems; therefore, buds were axillary (Fig. 3d). The buds were located preferentially in the first $5 \mathrm{~cm}$ and, in some cases, were displayed only after removing the protective scales (Fig. 3b, c) or the covering tissue (Fig. 3f).

\section{Belowground systems anatomy}

The belowground system of $E$. dysenterica is composed of a woody axis whose upper portion is a stem which emits aerial branches, while the lower portion consists of a thickened axial root that can reach up to $1 \mathrm{~m}$ deep (Figs. 4ad). The size of the belowground stem portion varies between individuals and can produce 

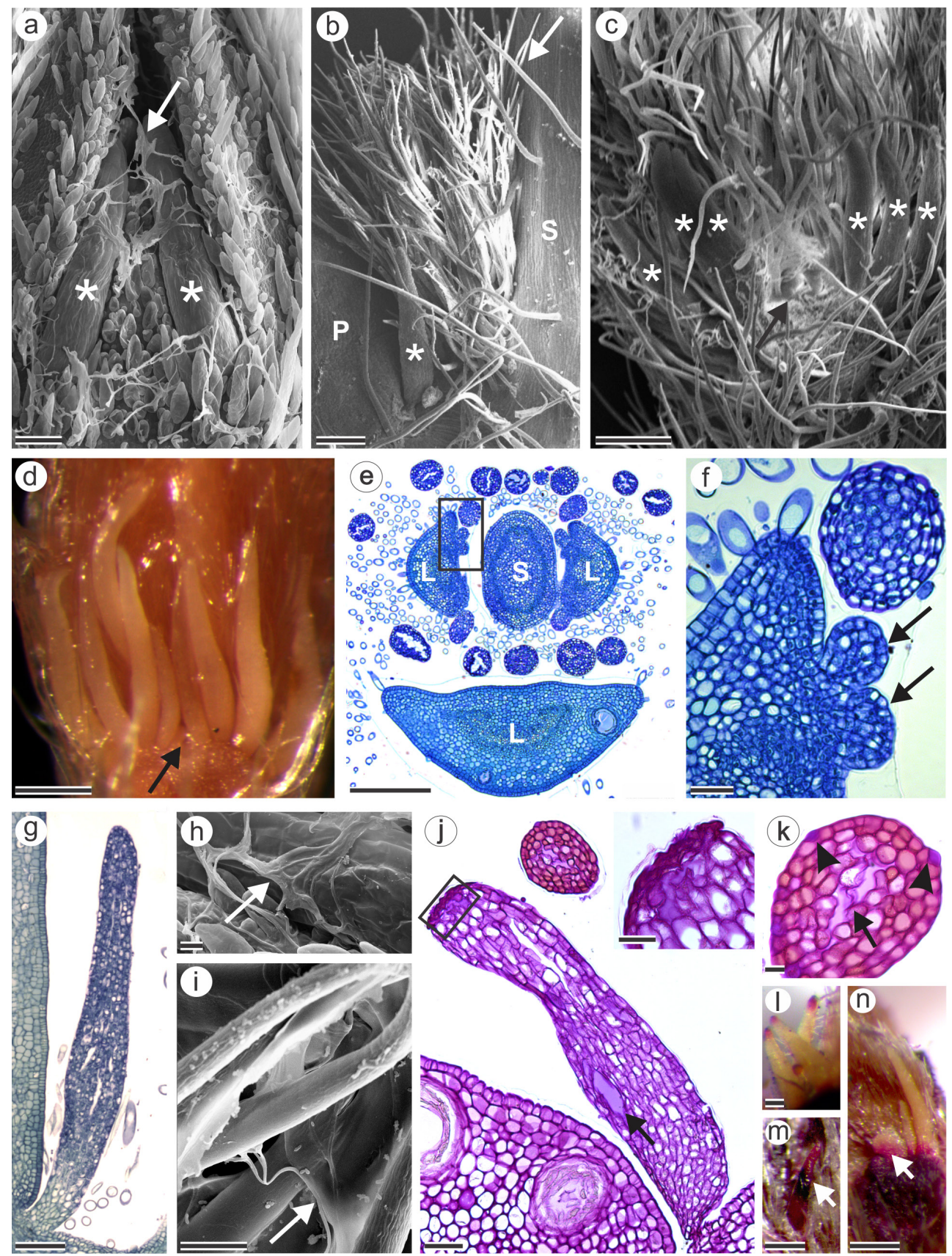

Figure 2 - Colleters of Eugenia dysenterica ( $(\mathbf{a}, \mathbf{c}, \mathbf{d}, \mathbf{e}, \mathbf{f}, \mathbf{i}, \mathbf{j}, \mathbf{k}, \mathbf{m})$ and E. punicifolia $(\mathbf{b}, \mathbf{g}, \mathbf{h}, \mathbf{l}, \mathbf{n})$. Scanning electron micrographs $(a-c, h, i)$, stereomicroscope photographs $(d, l-n)$, cross $(e, f, j, k)$ and longitudinal $(g)$ sections of the shoot apex. (a) Colleters (asterisks) releasing secretion (arrow). (b) Colleter (asterisk) on the lateral of the axillary bud (arrow). (c-d) Intrapetiolar colleters (c, asterisks) and axillary bud (arrow). (e) Colleters of circular diameter with large intercellular spaces in the parenchyma. (f) Detail of sector shown in (e). Two colleters in formation (arrows). (g) Lateral colleter stained by toluidine blue. (h-i) Secretion of sticky aspect (arrows). ( $\mathbf{j}, \mathbf{k}$ ) Colleters after positive reaction with PAS reagent. Secretion in the intercellular space (arrows) and released between the cells of the epidermis ( $k$, arrowheads). In the inset, collapsed cells after secretion. (l-n) Secretion evidenced by ruthenium red at the apex $(\mathrm{l})$, along the axis ( $\mathrm{m}$, arrow) and at the base of colleters and on axillary bud $(\mathrm{n}$, arrow). $\mathrm{L}=$ leaf primordium; $S=$ stem; $P=$ petiole. Bars: $d, e, m, n=250 \mu \mathrm{m} ; c=200 \mu \mathrm{m} ; \mathbf{b}=150 \mu \mathrm{m} ; \mathrm{a}, \mathbf{g}, \mathbf{l}=100 \mu \mathrm{m} ; \mathrm{j}=50 \mu \mathrm{m} ; \mathrm{f}$, inset $=25 \mu \mathrm{m} ; \mathrm{i}=15 \mu \mathrm{m}$ and $\mathrm{h}, \mathrm{k}=10 \mu \mathrm{m}$. 


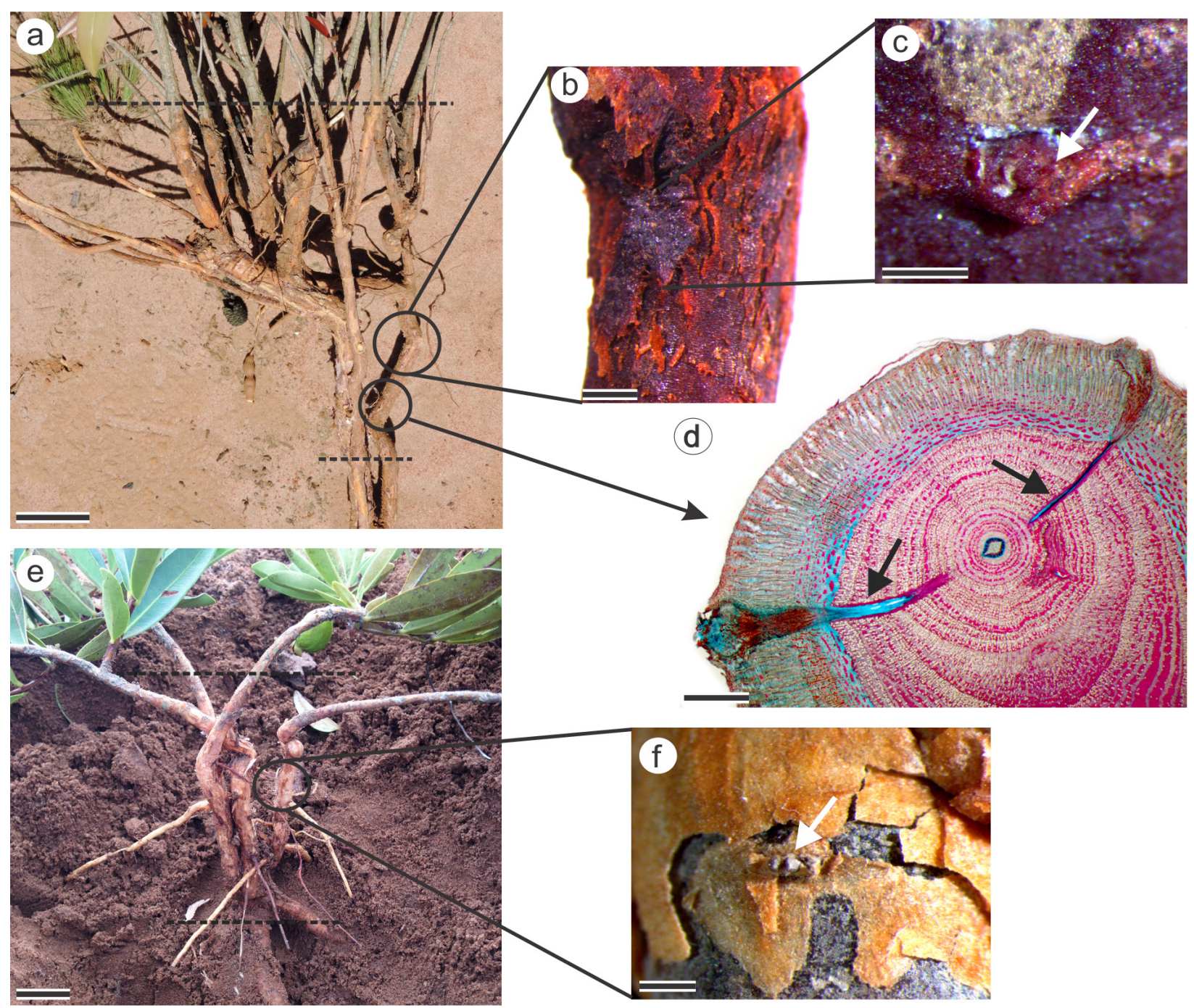

Figure 3 - Belowground systems with multiple branches of Eugenia dysenterica (a) and E. punicifolia (e) in the bud counting region (dashed lines). Bud of $E$. dysenterica protected by scale (b) and visualization after scale removal (c, arrow). Cross section of a branch of E. dysenterica. Note the shoot nature and the gap of two axillary buds (arrows) (d). Bud (arrow) of E. punicifolia protected by covering tissue (f). Bars: a, e $=2 \mathrm{~cm} ; \mathrm{b}, \mathrm{c}, \mathrm{d}, \mathrm{f}=1 \mathrm{~mm}$.

adventitious roots with slender and tuberized portions (Figs. 4a, iii and iv). The periderm that covers all the belowground axis consists of layers of suberized cells (Fig. 4e) containing phenolic compounds alternated with layers of cells whose inner periclinal walls are pectin thickened (Fig. 4f). Groups of fibriform sclereids are observed in the vascular cylinder, in the axial system of secondary phloem (Fig. 4g, arrows) and the parenchyma cells accumulate starch and phenolic compounds. The radial parenchyma cells are dilated in the outer portions of vascular rays and these cells accumulate phenolic compounds and starch (Fig. 4g). Phloem cells have a natural orange coloring content of phenolic nature. In the belowground axis non-tuberized portions, the secondary xylem presents a smaller number 

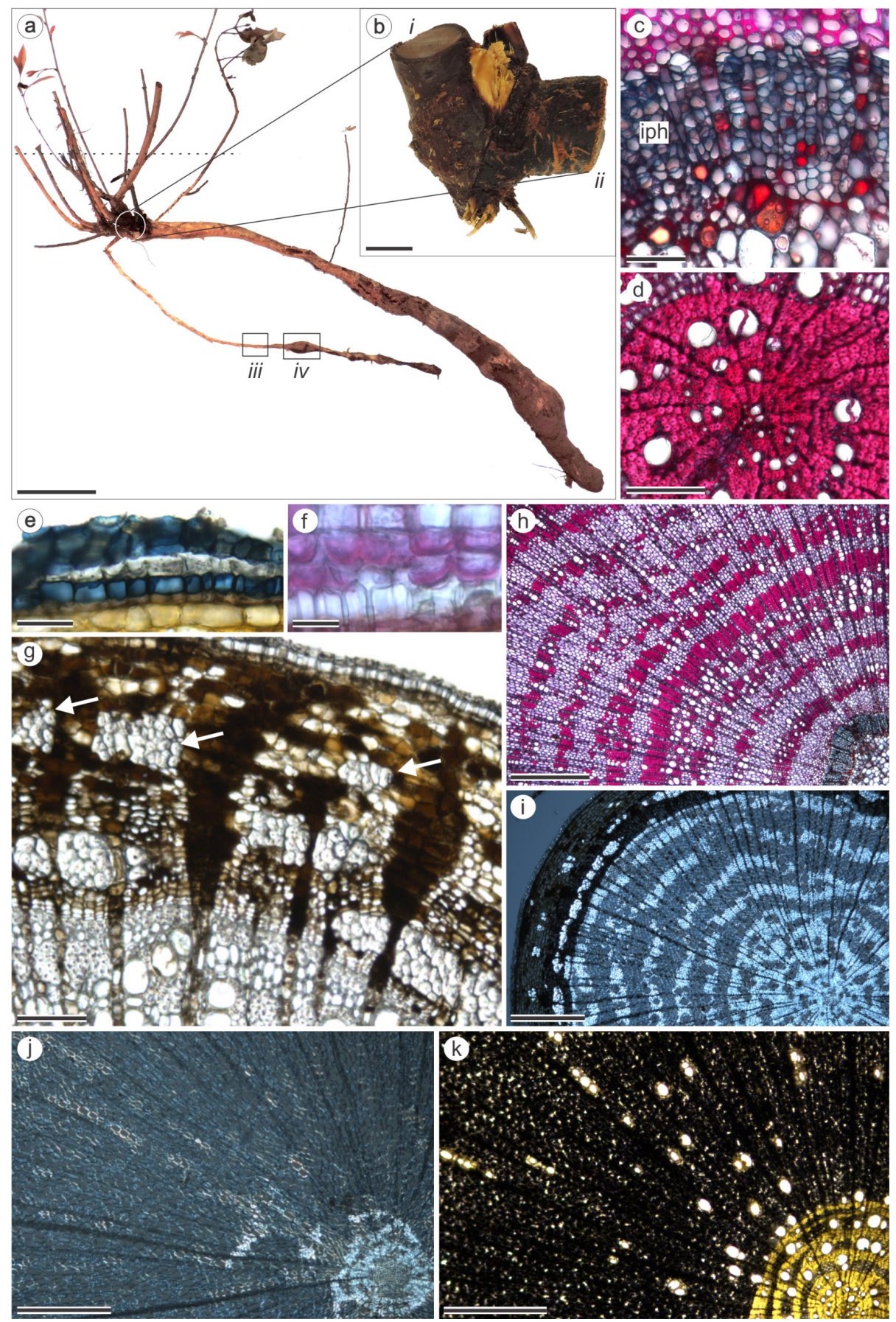

Figure 4 - (a) Belowground system (b.s.) of Eugenia dysenterica. (b) Detail of b.s. with stem portions ( $i$ ) and root (ii). (c-k) Cross sections. (c-d) Central vascular cylinder of the stem (c) and root (d) system. (e-f) Periderm with suberized walls cells stained by Sudan black B (e) alternating with cells of thickened walls in pectin stained by ruthenium red (f). (g) Secondary phloem with sclereids groups (arrows) and cells of axial and radial parenchyma with phenolic content evidenced by ferric chloride. ( $h$-i) Non-tuberized portions of b.s. with lignified secondary xylem stained with safranin ( $h$ ) and under polarized light (i). ( $j-k)$ Tuberized portions of b.s. with conspicuous vascular parenchyma ( $\mathrm{j}$, polarized light) with starch accumulation evidenced by zinc chloride iodine $(k)$. Dashed line = ground level. iph = internal phloem. Bars: $a=10 \mathrm{~cm} ; b=1 \mathrm{~cm} ; \mathrm{h}, \mathrm{i}, \mathrm{j}, \mathrm{k}=500 \mu \mathrm{m} ; \mathrm{d}, \mathrm{g}=100 \mu \mathrm{m} ; \mathrm{c}, \mathrm{e}=50 \mu \mathrm{m}$ and $\mathrm{f}=20 \mu \mathrm{m}$. 
of cells in axial and radial parenchyma and more lignified elements (Figs. 4h, i) when compared with the tuberized portions (Figs. $4 \mathrm{j}$, k). Therefore, starch accumulation is greater in tuberized portions (Fig. 4k). The caulinar axis has internal secondary phloem (Fig. 4C, h), with accumulation of phenolic compounds in the radial parenchyma and a prominent medulla composed of parenchyma cells containing phenolic compounds and scarce starch grains. In root portions, the exarch primary xylem occupies the center of the organ (Fig. 4d).

In E. punicifolia, the belowground stem forms horizontal portions by which aerial branches and adventitious roots are emitted. The taproot and the adventitious roots occupy a surface region of soil and, as well as the stem, they are distributed in a more horizontal plane (Fig. 5a). The periderm of the stem axis of E. punicifolia differs from the roots, since this tissue exhibits layers of cells with thickened lignified walls alternated with layers of cells with suberized walls (Figs. 5b, c). In the vascular cylinder of stem, the secondary phloem is well developed with dilated phloematic rays, whose dilatation results in a periclinal cell elongation and anticlinal divisions (Fig. 5d, e). There are calcium oxalate crystals and sclereids in the secondary phloem (Fig. 5f). Several cells of phloematic parenchyma contain natural orange coloring substance and others brownish hue (Fig. 5g), both react positively with ferric chloride and feature starch grains (Fig. 5h). Also in xylematic rays, in the internal phloem and medullary parenchyma, cells with orange content occur (Fig. 5i), which reacts positively to phenolic compounds (Fig. 5j), but starch grains are only observed in medullary cells.

In roots, regardless of the thickening degree, the periderm is similar to that described for the belowground stem and roots of E. dysenterica, with alternating layers of cells with suberized walls and cells with pectin-thickened walls (Fig. $5 k, l)$. In the vascular cylinder, secondary phloem parenchyma also features cells containing starch grains, some of which have natural orange content (Fig. $5 \mathrm{~m}$ ) of phenolic nature (Fig. $5 n)$ as observed in E. dysenterica. Similar to the belowground stem, phloematic rays present anticlinal divisions and tangential expansion of cells whose intensity depends on the thickening degree of roots (Fig. 50). There are calcium oxalate crystals and sclereids in phloematic parenchyma (Fig. 5p). In secondary xylem, the vascular rays accumulate phenolic compounds (Fig. 5n) and starch grains. Inside the primary exarch xylem, cells can be lignified (Fig. 5q) or not (Fig. 5r).

\section{Root chemical composition analysis}

Total of free carbohydrates contents in roots of E. dysenterica and E. punicifolia were $4.17 \mathrm{~g} 100 \mathrm{~g}^{-1}$ of roots and $4.46 \mathrm{~g} 100 \mathrm{~g}^{-1}$ of roots, respectively. The content, without significant difference by the Tukey test ( $1 \%$ probability), refers to the concentration of carbohydrates solubilized in aqueous medium after maceration, and the insoluble material (fibers) was not analyzed. The species presented significant differences by the Tukey test (1\% probability) with respect to concentrations of total phenolics compounds, being $2.54 \mathrm{mg}$ per $100 \mathrm{~g}$ of root (TAE) for $E$. dysenterica and $13.66 \mathrm{mg}$ per $100 \mathrm{~g}$ of root (TAE) for E. punicifolia. The concentrations of total flavonoids also presented significant differences by the Tukey test (1\% probability) between species, being $1.18 \mathrm{mg}$ per $100 \mathrm{~g}$ of root for E. dysenterica and 7.28 for $100 \mathrm{~g}$ of root for $E$. punicifolia. Analytical quantification of chemical components highlights their presence in the individuals studied. 


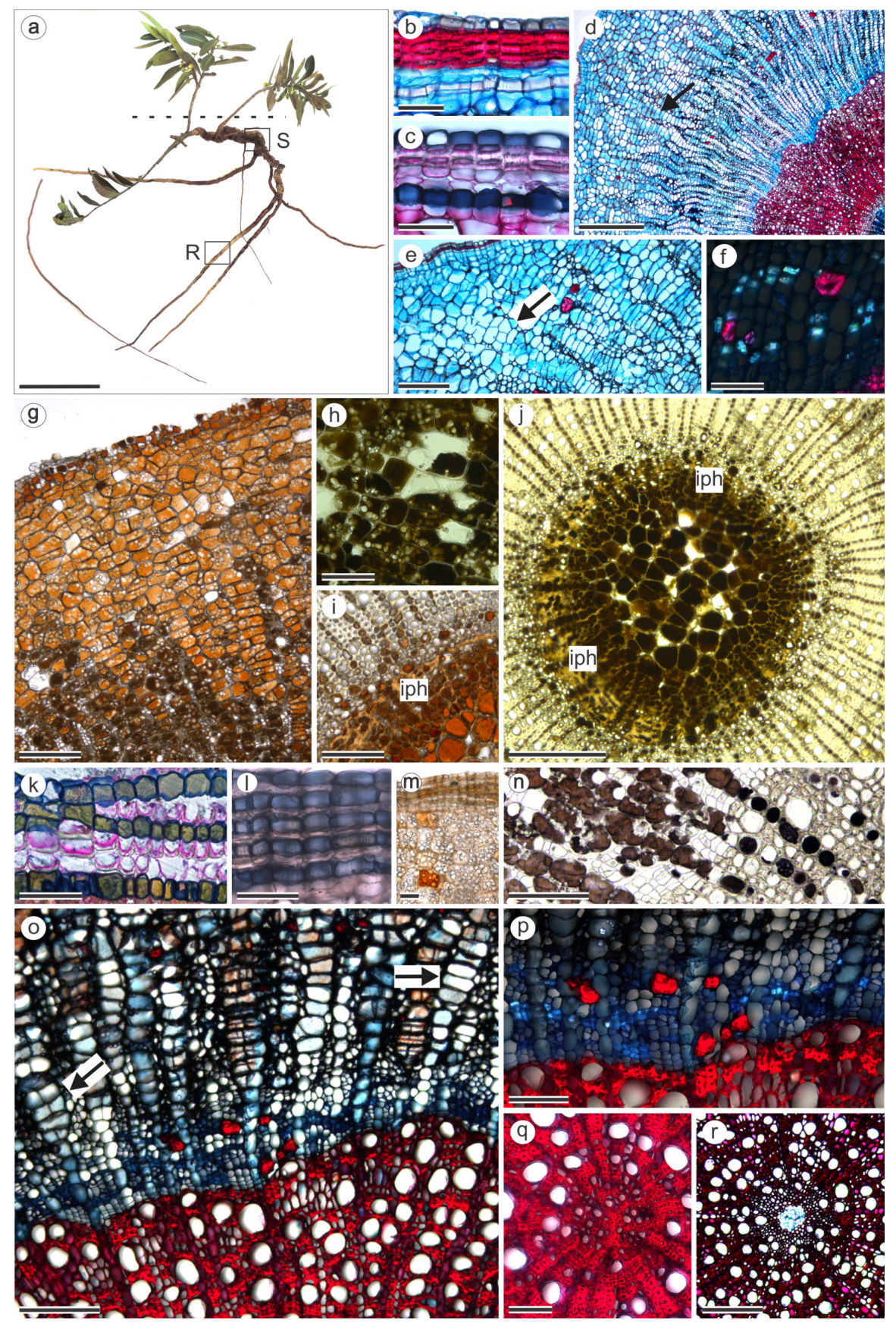

Figure 5 - (a) Belowground system of Eugenia punicifolia. (b-r) Cross sections of the stem (b-j) and roots (k-r). (n) Section of material fixed in formalin-ferrous sulphate. (b-c) Periderm with cells of thickened walls in lignin stained by safranin (b) alternating with cells of suberized walls stained by Sudan black B (c). (d-e) Dilated phloematic rays (arrows). (f) Secondary phloem with prismatic crystals and sclereids. (g-h) Phloematic parenchyma cells with orange content (g) that reacts positively to ferric chloride $(\mathrm{h})$. (i-j) Xylematic rays, parenchyma cells of the internal phloem and medullary cells with internal orange content (i) that reacts positively to ferric chloride (j). (k-l) Periderm with cells of suberized walls stained with Sudan black $B$ and cells with thickened walls in pectin stained by ruthenium red $(k)$. ( $m-n)$ Orange colored cells $(m)$ of phenolic nature $(n)$. (o) Dilated phloematic rays (arrows). (p) Secondary phloem with prismatic crystals and sclereids observed under polarized light. (q-r) Center of the vascular cylinder with lignified $(q)$ or non-lignified cells $(r)$. Dashed line $=$ ground level. $i p h=$ internal phloem. Bars: $\mathrm{a}=10 \mathrm{~cm} ; \mathrm{d}=500 \mu \mathrm{m} ; \mathrm{j}=250 \mu \mathrm{m} ; \mathrm{e}, \mathrm{g}, \mathrm{o}, \mathrm{r}=200 \mu \mathrm{m} ; \mathrm{h}, \mathrm{i}, \mathrm{n}, \mathrm{p}=100 \mu \mathrm{m} ; \mathrm{b}, \mathrm{c}, \mathrm{f}, \mathrm{k}, \mathrm{l}, \mathrm{m}, \mathrm{q}=50 \mu \mathrm{m}$. 


\section{DISCUSSION}

\section{Bud protection}

Protection strategies for aerial buds observed in Eugenia dysenterica and E. punicifolia are similar to those found in Australian Myrtaceae species, such as the presence of leaf primordia with many non-glandular trichomes (NGT) at the abaxial surface (Burrows 2008) which accumulate phenolic compounds (Burrows et al. 2008). The phenolic compounds are secondary metabolites present in many species of Eugenia L. (Auricchio \& Bacchi 2003, Armstrong et al. 2012, Takao et al. 2015) and are involved with chemical defense mechanisms in plants against pathogens (Bennett \& Wallsgrove 1994), herbivory (Bellingham \& Sparrow 2000), in addition to minimizing exposure of aerial organs to UV rays (Lambers et al. 2008). In the studied species, NGT have cellulose thickened cell walls and are whitish, as observed in other species (Lee 2010, Yamazaki 2017, Yamazaki \& Lev-Yadun 2015), being related to tissue protection against UV rays and drought, as well as predation. Moreover, secretory cavities of lipophilic substances, such as those observed in leaf primordia of buds of both species and in other Eugenia species (Armstrong et al. 2012), have been related to chemical defense against herbivory (Maffei 2010). Calcium oxalate crystals found in studied Eugenia species and many others Myrtaceae species (Retamales et al. 2014, Pacheco-Silva \& Donato 2016) have been associated with non-nutritive defense mechanisms of plants, reducing attacks by insects (Korth et al. 2006).

\section{Colleters}

The exudate of colleters of the analyzed species reacts positively to detection of polysaccharides, commonly found in these structures (Silva et al. 2017, Ribeiro et al. 2017), which confirms its mucilaginous nature, responsible for its main function, which is to protect the meristem (Ribeiro et al. 2017). In addition to meristem protection, the presence of secretion and location of the colleters highlight the importance of these structures for protection of buds against excessive sunlight and high transpiration levels, reducing water loss (Oliveira et al. 2017), proliferation of fungi (Ribeiro et al. 2017), as well as can be considered as an adaptive factor in Myrtoideae (Silva et al. 2012). Colleters found in this work are the conic type, following the classification proposed by Silva et al. (2012), due to its circular format in cross section with decreasing diameter from base to apex. This type of colleter was observed in 19 species of Myrtoideae near the shoot apical meristem at the stem apex and in leaf axils (Silva et al. 2012). However, this is the first record of colleters in E. dysenterica and E. punicifolia, which are emergences originated from protoderm and ground meristem, a trait observed in species of Rubiaceae (Vitarelli \& Santos 2009, Coelho et al. 2013) and Apocynaceae (Appezzato-daGlória \& Estelita 2000a). In the colleters of those families, the palisade epidermis is responsible for exudate secretion (Appezzato-da-Glória \& Estelita 2000a, Martins et al. 2010b, Coelho et al. 2013). However, in the studied species and in the Myrtaceae species analyzed by Silva et al. (2012), epidermal cells are not elongated radially, but with a dense cytoplasm and positive reaction for total polysaccharides test. These characteristics are also observed in the parenchyma cells throughout the colleter axis, except on the peduncle when present. This homogeneous pattern of cells observed in colleters of Eugenia in this study and in Silva et al. (2012) has also been described in Fabaceae colleters (Paiva and Machado 2006, Coutinho et al. 2015, Silva et al. 2017). 
In Eugenia dysenterica and E. punicifolia, the parenchyma has intercellular spaces typical of the ground tissue before the secretory phase; however, during the secretory phase, there is an increase of these spaces and exudate accumulation. This intercellular accumulation of secretion has been reported in other Myrtaceae species (Silva et al. 2012) and Hymenaea stigonocarpa - Fabaceae: Caesalpinioideae (Paiva \& Machado 2006). These authors found pectic compounds in intercellular spaces and in the cytosol in all the parenchyma cells of colleter axis, as described in this paper. Colleters are not vascularized, as verified in other species (Martins et al. 2010b, Silva et al. 2017, Ribeiro et al. 2017). Secretion in colleters in E. dysenterica and E. punicifolia is released through spaces that form between the epidermal cells. This feature has been observed in species of Apocynaceae (Appezzato-da-Glória \& Estelita 2000a, Martins et al. 2010b); however, in Myrtaceae, this is the first report of the secretion release process. Senescence of the analyzed colleters is initiated at the end of the secretory phase and characterized by brownish coloration at the colleter apex (Silva et al. 2012). The color change has been linked to oxidation of phenolic compounds as a product of senescence in apex cells (Coelho et al. 2013), followed by a collapse of these cells (L.A. Souza, unpublished data) as verified in E. dysenterica and E. punicifolia.

\section{Belowground bud bank}

The belowground systems of the analyzed species are soboles (woody rhizomes) whose upper portion emits horizontal stem branches that extend belowground level and form aerial projections and adventitious roots (Pausas et al. 2018). Among the 358 Myrtaceae species from worldwide fire-prone ecosystems listed by Pausas et al. (2018) in the supplementary database, all of them present lignotuber and only eight species have lignotuber and woody rhizome.

Studies on belowground bank buds with Cerrado species have shown a greater concentration of buds in the organ portion closer to ground level (Alonso \& Machado 2007, Appezzato-da-Glória and Cury 2011, Bombo et al. 2014, Filartiga et al. 2017a, b), as observed in this work. Buds protection is an important trait in maintaining a viable bud bank, as these buds are protected by the soil (Vesk and Westoby 2004, Alonso \& Machado 2007, Clarke et al. 2013). In addition, belowground buds in E. dysenterica and in other Cerrado species (Alonso \& Machado 2007, Appezzato-da-Glória et al. 2008) are equipped with thick scales, which also confer protection to the shoot apical meristem.

\section{Storage and protective compounds}

Starch was found in large quantities in the studied Eugenia species. This carbohydrate provides direct energy to resprouting (Orthen 2001) and structural carbon necessary for the formation of new tissues during resprouting (De Moraes et al. 2016). In Eugenia dysenterica and E. punicifolia, as well as in thickened belowground organs of other species, reserve accumulation is usually related to the increase of number of cells in vascular parenchyma (Bell et al. 1996, Appezzato-da-Glória 2015, Abdalla et al. 2016). In E. dysenterica, starch accumulation is more prominent in the axial and radial parenchyma cells of secondary xylem, while in E. punicifolia accumulation occurs in cells of the phloematic parenchyma. In both species, there is no variation in cambium activity for the production of vascular parenchyma; however, there are anticlinal divisions and expansions of tangential walls of phloematic parenchyma cells that promote increase in organ thickness, mainly, in $E$. punicifolia. Soffiatti \& Angyalossy-Alfonso (1999) also observed expansion of radial parenchyma 
cells forming a disordered array with the presence of crystals in Eugenia cerasiflora and E. uniflora and sclereids groups in E. uniflora. In Eugenia dysenterica and E. punicifolia, crystals and lignified sclereids groups are also observed in the secondary phloem. These structures are important for protection of belowground axis mainly against insect attack (Hudgins et al. 2003). In the belowground stem of both species and in Eugenia pyriformis (Armstrong et al. 2012), there is an inner phloem, which is a diagnostic feature in Myrtaceae (Metcalfe \& Chalk 1950). On the root periderm of both species, there are alternating cell layers of suberized walls and cells with parietal thickenings in pectin. Given the hydrophilic pectin properties (Paiva et al. 2009), walls with pectic thickenings may be retaining moisture in the covering tissue. Furthermore, in the periderm of stem of E. punicifolia, there was the presence of cell layers with lignified walls, as reported in other Myrtaceae (Soffiatti \& Angyalossy-Alfonso 1999, Armstrong et al., 2012) and in the terminal portion of soboles in Erythroxylum nanum (Alonso \& Machado 2007).

In regard the reserve carbohydrates in studied Eugenia species, other compounds can be directly related to protection of belowground structures and, therefore, with the survival and resprouting potential of these plants. In the studied species, phenolic compounds were detected, not only on periderm, which is a frequent feature in belowground organs of Cerrado species (Appezzato-da-Glória \& Cury 2011, Joaquim et al. 2014), but also in cells of the phloematic, xylematic and medullary parenchyma (when present). Some phenolic compounds and flavonoids may reduce digestibility for herbivores and act as phytoalexins, phytoanticipins and nematicides (Akhtar \& Malik 2000, Kefeli et al. 2003, Howe \& Schaller 2008, Bhattacharya et al. 2010). In addition, these compounds can polymerize and biosynthesize lignin, consequently strengthening cell walls (Kefeli et al. 2003, Bhattacharya et al. 2010). The difference in concentrations of phenolic compounds in $E$. dysenterica and E. punicifolia may indicate that roots of E. punicifolia have higher probability of antioxidant action and possible protection against attacks of nematodes and pests. In addition to phenolic compounds, flavonoids may also perform protection functions of belowground systems in the studied species, for example, by lignin polymerization for support and the antimicrobial action (Ferrer et al. 2008).

In conclusion, the high protection degree of buds in aerial organs, the presence and large number of buds in belowground structures, the accumulation of reserves and protection in belowground organs may have favored permanence of Eugenia dysenterica and $E$. punicifolia in the Cerrado region, as well as their resprouting after the clear-cutting of Pinus trees and burning of pine needles. In addition, the morphoanatomical and chemical characteristics presented are relevant to studies on the protection strategies and regeneration of plants subjected to environmental disturbances.

\section{Acknowledgments}

The authors thank the Conselho Nacional de Desenvolvimento Científico e Tecnológico (CNPq) for grant (Proc. n 303715/2014-6) and for granting scholarship to the first author (Proc. n. 130317/2016-0). This study was financed by Coordenação de Aperfeiçoamento de Pessoal de Nível Superior (CAPES - Brasil - Finance Code 001) and by Fundação de Amparo a Pesquisa do Estado de São Paulo (FAPESP - proc. 2018/18887-5). We are grateful to the Instituto Florestal/COTEC (Proc. SMA 260108 - 003.809/2016) in giving permission to collect plant materials, NAP-MEPA, ESALQ/USP for electron microscope facilities, Natashi Pilon for species identification and Marli K. M. Soares for technical assistance. 


\section{REFERENCES}

ABDALLA DF, MORAES MG, REZENDE MH, HAYASHI AH \& CARVALHO MAM. 2016. Morpho-anatomy and fructans in the underground system of Apopyros warmingii and Ichthyothere terminalis (Asteraceae) from the cerrado rupestre. J Torrey Bot Soc 143: 69-86.

AKHTAR M \& MALIK A. 2000. Roles of organic soil amendments and soil organisms in the biological control of plant-parasitic nematodes: a review. Bioresour Technol 74: 35-47.

ALONSO AA \& MACHADO SR. 2007. Morphological and developmental investigations of the underground system of Erythroxylum species from Brazilian cerrado. Aust J Bot 55: 749-758.

APPEZZATO-DA-GLÓRIA B. 2015. Morfologia de Sistemas Subterrâneos de Plantas. Ed. 3i. Belo Horizonte, 80 p.

APPEZZATO-DA-GLÓRIA B \& CURY G. 2011. Morpho-anatomical features of underground systems in six Asteraceae species from the Brazilian Cerrado. An Acad Bras Cienc 83: 981-992.

APPEZZATO-DA-GLÓRIA B, CURY G, SOARES MKM, ROCHA R \& HAYASHI AH. 2008. Underground systems of Asteraceae species from the Brazilian Cerrado. J Torrey Bot Soc 135: 103-113.

APPEZZATO-DA-GLÓRIA B \& ESTELITA ME. 2000a. Development, structure and distribution of colleters in Mandevilla illustris and M. velutina (Apocynaceae). Rev Bras Bot 23: 113-120.

APPEZZATO-DA-GLÓRIA B \& ESTELITA ME. 2000b. The developmental anatomy of the subterranean system in Mandevilla illustris (Vell.) Woodson and M. velutina (Mart. ex Stadelm.) Woodson (Apocynaceae). Rev Bras Bot 23: 27-35.

ARMSTRONG L, DUARTE MDR \& MIGUEL OG. 2012. Morphoanatomy of the leaf and stem of Eugenia pyriformis. Rev Bras Farmacogn 22: 475-481.

ASEGA AF, NASCIMENTO JRO \& CARVALHO MAM. 2011. Increased expression of fructan 1-exohydrolase in rhizophores of Vernonia herbacea during sprouting and exposure to low temperature. J Plant Physiol 168: 558-565.

AURICCHIO MT \& BACCHI EM. 2003. Folhas de Eugenia uniflora L. (pitanga): propriedades farmacobotânicas, químicas e farmacológicas. Rev Inst Adolfo Lutz 62: 55-61.

BELL AD, BELL A \& DINES TD. 1999. Branch construction and bud defence status at the canopy surface of a West African rainforest. Biol J Linn Soc 66: 481-499.
BELL TL, PATE JS \& DIXON KW. 1996. Relationships between fire response, morphology, root anatomy and starch distribution in south-west Australian Epacridaceae. Ann Bot 77: 357-364.

BELLINGHAM PJ \& SPARROW AD. 2000. Resprouting as a life history strategy in woody plant communities. Oikos 89 : 409-416.

BENNETT RN \& WALLSGROVE RM. 1994. Secondary metabolites in plant defence mechanisms. New Phytol 127: 617-633.

BHATTACHARYA A, SOOD P \& CITOVSKY V. 2010. The roles of plant phenolics in defense and communication during Agrobacterium and Rhizobium infection. Mol Plant Pathol 11: 705-719.

BOMBO AB, OLIVEIRA TS, OLIVEIRA ASS, REHDER VLG \& APPEZZATO-DA-GLÓRIA B. 2014. Anatomy and essential oil composition of the underground systems of three species of Aldama La Llave (Asteraceae). J Torrey Bot Soc 141: $115-125$.

BRUM M, TEODORO GS, ABRAHÃO A \& OLIVEIRA RS. 2017. Coordination of rooting depth and leaf hydraulic traits defines drought-related strategies in the campos rupestres, a tropical montane biodiversity hotspot. Plant Soil 420: 467-480.

BURROWS GE. 2008. Syncarpia and Tristaniopsis (Myrtaceae) possess specialised fire-resistant epicormic structures. Aust J Bot 56: 254-264.

BURROWS GE \& CHISNALL LK. 2016. Buds buried in bark: the reason why Quercus suber (cork oak) is an excellent post-fire epicormic resprouter. Trees 30: 241-254.

BURROWS GE, HORNBY SK, WATERS DA, BELLAIRS SM, PRIOR LD \& BOWMAN DMJS. 2008. Leaf axil anatomy and bud reserves in 21 Myrtaceae species from northern Australia. Int J Plant Sci 169: 1174-1186.

CHARLES-DOMINIQUE T, BECKETT H, MIDGLEY GF \& BOND WJ. 2015. Bud protection: a key trait for species sorting in a forest-savanna mosaic. New Phytol 207: 1052-1060.

CLARKE PJ, LAWES MJ, MIDGLEY JJ, LAMONT BB, OJEDA F, BURROWS GE \& KNOX KJE. 2013. Resprouting as a key functional trait: how buds, protection and resources drive persistence after fire. New Phytol 197: 19-35.

COELHO VPM, LEITE JPV, FIETTO LG \& VENTRELLA MC. 2013. Colleters in Bathysa cuspidata (Rubiaceae): development, ultrastructure and chemical composition of the secretion. Flora 208: 579-590.

COUTINHO ÍAC, FRANCINO DMT \& MEIRA RMSA. 2015. New records of colleters in Chamaecrista (Leguminosae, 
Caesalpinioideae SL): structural diversity, secretion, functional role, and taxonomic importance. Int J Plant Sci 176: 72-85.

DE MORAES MG, CARVALHO MAM, FRANCO AC, POLLOCK CJ \& FIGUEIREDO-RIBEIRO RDCL. 2016. Fire and Drought: Soluble Carbohydrate Storage and Survival Mechanisms in Herbaceous Plants from the Cerrado. BioScience 66: 107-117.

DIAS-TAGLIACOZZO GM, ITAYA NM, CARVALHO M, FIGUEIREDORIBEIRO RDCL \& DIETRICH S. 2004. Fructans and water suppression on intact and fragmented rhizophores of Vernonia herbacea. Braz Arch Biol Technol 47: 363-373.

DUBOIS M, GILLES KA, HAMILTON JK, REBERS PAT \& SMITH F. 1956. Colorimetric method for determination of sugars and related substances. Anal Chem 28: 350-356.

FERRAZ A, MENDONÇA R \& SILVA FT. 2000. Organosolv delignification of white-and brown-rotted Eucalyptus grandis hardwood. J Chem Technol Biotechnol 75: 18-24.

FERRER JL, AUSTIN MB, STEWART C \& NOEL JP. 2008. Structure and function of enzymes involved in the biosynthesis of phenylpropanoids. Plant Physiol Biochem 46: 356-370.

FIASCHI P \& PIRANI JR. 2009. Review of plant biogeographic studies in Brazil. J Syst Evol 47: 477-496.

FILARTIGA AL, BOMBO AB, GARCIA VL \& APPEZZATO-DA-GLÓRIA B. 2017a. Belowground organs of four Brazilian Aldama (Asteraceae) species: Morphoanatomical traits and essential oil profile. S Afr J Bot 113: 150-159.

FILARTIGA AL, KLIMEŠOVÁ J \& APPEZZATO-DA-GLÓRIA B. 2017b. Underground organs of Brazilian Asteraceae: testing the CLO-PLA database traits. Folia Geobot 1-19.

FISHER DB. 1968. Protein staining of ribboned epon sections for light microscopy. Histochemie 16: 92-96.

GERLACH D. 1984. Botanische Mikrotechnik. New York: Georg Thieme Verlag, 311 p.

GREGORY M \& BAAS P. 1989. A survey of mucilage cells in vegetative organs of the dicotyledons. Israel J Bot 38: 125-174.

HAHLBROCK K \& SCHEEL D. 1989. Physiology and molecular biology of phenylpropanoid metabolism. Annu Rev Plant Physiol Plant Mol Biol 40: 347-369.

HAYASHI AH \& APPEZZATO-DA-GLÓRIA B. 2009. Resprouting from roots in four Brazilian tree species. Rev Biol Trop 57: 789-800.

HORRIDGE GA \& TAMM SL. 1969. Critical point drying for scanning electron microscopy study of ciliary motion. Science 163: 817-818.
HOWE GA \& SCHALLER A. 2008. Direct defenses in plants and their induction by wounding and insect herbivores. In: Schaller A (Ed), Induced plant resistance to herbivory. Netherlands: Springer 7-29 p.

HUDGINS JW, KREKLING T \& FRANCESCHI VR. 2003. Distribution of calcium oxalate crystals in the secondary phloem of conifers: a constitutive defense mechanism? New Phytol 159: 677-690.

HUGHES J \& MCCULLY ME. 1975. The use of an optical brightener in the study of plant structure. Stain Technol 50: 319-452.

JENSEN WA. 1962. Botanical histochemistry: principles and practice. San Francisco: W. H. Freeman, 408 p.

JOAQUIMEDO, FIGUEIREDO-RIBEIRO RCL, HAYASHIAH \& CARVALHO MAM. 2014. Inulin contents and tissue distribution in underground storage organs of Asteraceae species from the Brazilian rocky fields. Botany 92: 827-836.

JOHANSEN DA. 1940. Plant microtechnique. New York: McGraw-Hill, 523 p.

KARNOVSKY JM. 1965. A formaldehyde-glutaraldehyde fixative of high osmolality for use in electron microscopy. J Cell Biol 27: 137-138.

KEFELI VI, KALEVITCH MV \& BORSARI B. 2003. Phenolic cycle in plants and environment. J Cell Mol Biol 2: 13-18.

KLIMEŠOVÁ J \& KLIMEŠ L. 2007. Bud banks and their role in vegetative regeneration - A literature review and proposal for simple classification and assessment. Perspect Plant Ecol Evol Syst 8: 115-129.

KORTH KL, DOEGE SJ, PARK SH, GOGGIN FL, WANG Q, GOMEZ SK \& NAKATA PA. 2006. Medicago truncatula mutants demonstrate the role of plant calcium oxalate crystals as an effective defense against chewing insects. Plant Physiol 141: 188-195.

LAMBERS H, CHAPIN FS \& PONS TL. 2008. Photosynthesis. In: Plant physiological ecology. New York: Springer, 11-99 p.

LEE D. 2010. Nature's palette: the science of plant color. Chicago: University of Chicago Press, 85 p.

LOPES-MATTOS KLB, AZEVEDO AA, SOARES AA \& MEIRA RMSA. 2013. Underground system of Mandevilla atroviolacea (Stadelm.) Woodson (Apocynaceae, Apocynoideae) from the Brazilian high-altitude grassland. S Afr J Bot 87: 27-33.

LUQUE R, SOUSA H \& KRAUS JE. 1996. Métodos de Coloração de Roeser (1972) modificado e Kropp (1972) visando a substituição do azul de astra por azul de alcião 8GS e 8GX. Acta Bot Bras 10: 199-211. 
MAFFEI ME. 2010. Sites of synthesis, biochemistry and functional role of plant volatiles. S Afr J Bot 76: 612-631.

MARTINS AR, PÜTZ N, SOARES AN, BOMBO AB \& APPEZZATODA-GLÓRIA B. 2010a. New approaches to underground systems in Brazilian Smilax species (Smilacaceae). J Torrey Bot Soc 137: 220-235.

MARTINS FM, KINOSHITA LS \& CASTRO MDM. $2010 \mathrm{~b}$. Coléteres foliares e calicinais de Temnadenia violacea (Apocynaceae, Apocynoideae): estrutura e distribuição. Rev Bras Bot 33: 489-500.

MCMANUS JFA. 1948. Histological and histochemical uses of periodic acid. Stain Technol 23: 99-108.

MENDONÇA RC, FELFILI JM, WALTER BMT, SILVA-JÚNIOR MC, REZENDE AV, FILGUEIRAS TS, NOGUEIRA PE \& FAGG CW. 2008. Flora vascular do bioma Cerrado: checklist com 12.356 espécies. In: Cerrado: ecologia e flora. Brasília: Embrapa Cerrados/Embrapa Informação Tecnológica, 423-1279 p.

METCALFE CR \& CHALK L. 1950. Anatomy of the Dicotyledons: leaves, stem and wood in relation to taxonomy with notes on economic uses. Oxford: Clarendon Press, 1500 p.

MILANEZ CR \& MORAES-DALLAQUA MA. 2003. Ontogeny of the subterranean system of Pachyrhizus ahipa (Wedd.) Parodi (Fabaceae). Rev Bras Bot 26: 415-427.

OLIVEIRA CS, SALINO A \& PAIVA EAS. 2017. Colleters in Thelypteridaceae: Unveiling mucilage secretion and its probable role in ferns. Flora 228: 65-70.

ORTHEN B. 2001. Sprouting of the fructan-and starchstoring geophyte Lachenalia minima: Effects on carbohydrate and water content within the bulbs. Physiol Plant 113: 308-314.

PACHECO-SILVA NV \& DONATO AM. 2016. Morpho-anatomy of the leaf of Myrciaria glomerata. Rev Bras Farmacogn 26: 275-280.

PAIVA ÉAS \& MACHADO SR. 2006. Ontogenesis, structure and ultrastructure of Hymenaea stigonocarpa (Fabaceae: Caesalpinioideae) colleters. Rev Biol Trop 54: 943-950.

PAIVA EP, LIMA MS \& PAIXÃO JA. 2009. Pectina: propriedades químicas e importância sobre a estrutura da parede celular de frutos durante o processo de maturação. Rev Iberoam Polím 10: 196-211.

PARK YK, KOO MH, SATO HH \& CONTADO JL. 1995. Estudo de alguns componentes da própolis coletada por Apis mellifera no Brasil. Arq Biol Tecnol 38: 1253-1259.

PAULA S, NAULIN PI, ARCE C, GALAZ C \& PAUSAS JG. 2016. Lignotubers in Mediterranean basin plants. Plant Ecol 217: 661-676.
PAUSAS JG, LAMONT BB, PAULA S, APPEZZATO-DA-GLÓRIA B \& FIDELIS A. 2018. Unearthing belowground bud banks in fire-prone ecosystems. New Phytol 217: 1435-1448.

PEARSE AGE. 1968. Histochemistry: Theoretical and applied. London: J. \& A. Churchill Ltd, 998 p.

PEREIRA-JÚNIOR AC, OLIVEIRA SL, PEREIRA JM \& TURKMAN MAA. 2014. Modelling fire frequency in a Cerrado savanna protected area. PloS One 9: e102380.

RETAMALES HA, SCHERSON R \& SCHARASCHKIN T. 2014. Foliar micromorphology and anatomy of Ugni molinae Turcz. (Myrtaceae), with particular reference to schizogenous secretory cavities. Rev Chil Hist Nat 87: 27.

RIBEIRO JC, FERREIRA MJP \& DEMARCO D. 2017. Colleters in Asclepiadoideae (Apocynaceae): Protection of meristems against desiccation and new functions assigned. Int J Plant Sci 178: 465-477.

RODRIGUES RR, TORRES RB, MATTHES LA \& PENHA AS. 2004. Tree species sprouting from root buds in a semideciduous forest affected by fires. Braz Arch Biol Technol 47: 127-133.

SAKAI WS. 1973. Simple method for differential staining of paraffin embedded plant material using toluidine blue O. Stain Technol 48: 247-249.

SILVA CJ, BARBOSA LCDA, MARQUES AE, BARACAT-PEREIRA MC, PINHEIRO AL \& MEIRA RM. 2012. Anatomical characterisation of the foliar colleters in Myrtoideae (Myrtaceae). Aust J Bot 60: 707-717.

SILVA MDS, COUTINHO ÍAC, ARAÚJO MN \& MEIRA RMSA. 2017. Colleters in Chamaecrista (L.) Moench sect. Chamaecrista and sect. Caliciopsis (Leguminosae-Caesalpinioideae): anatomy and taxonomic implications. Acta Bot Bras 31: 382-391.

SIMON MF, GRETHER R, QUEIROZ LP, SKEMA C, PENNINGTON RT \& HUGHES CE. 2009. Recent assembly of the Cerrado, a neotropical plant diversity hotspot, by in situ evolution of adaptations to fire. Proc Natl Acad Sci USA 106: 20359-20364.

SOBRAL M, PROENÇA C, SOUZA M, MAZINE F \& LUCAS E. 2015. Myrtaceae in Lista de Espécies da Flora do Brasil. Jardim Botânico do Rio de Janeiro. http://floradobrasil.jbrj.gov. br/jabot/floradobrasil/FB10515. Acesso em: 04 Ago 2018.

SOFFIATTI P \& ANGYALOSSY-ALFONSO V. 1999. Estudo anatômico comparativo do lenho e da casca de duas espécies de Eugenia L. (Myrtaceae). Rev Bras Bot 22: $175-184$.

STRASBURGER E. 1913. Handbook of Practical Botany. London: George Allen \& Company Ltda, 118 p. 
TAKAO LK, IMATOMI M \& GUALTIERI SCJ. 2015. Antioxidant activity and phenolic content of leaf infusions of Myrtaceae species from Cerrado (Brazilian Savanna). Braz J Biol 75: 948-952.

VESK PA \& WESTOBY M. 2004. Sprouting ability across diverse disturbances and vegetation types worldwide. J Ecol 92: 310-320.

VITARELLI NC \& SANTOS M. 2009. Stipule and colleter anatomy of Psychotria carthagenensis Jacq.(Rubiaceae). Acta Bot Bras 23: 923-928.

WILDY DT \& PATE JS. 2002. Quantifying above- and belowground growth responses of the Western Australian Oil Mallee, Eucalyptus kochii subsp. plenissima, to contrasting decapitation regimes. Ann Bot 90: 185-197.

YAMAZAKI K. 2017. White plant shoots, wax-producing insects and other white structures made by arthropods: A mimicry complex? Eur J. Entomol 114: 343.

YAMAZAKI K \& LEV-YADUN S. 2015. Dense white trichome production by plants as possible mimicry of arthropod silk or fungal hyphae that deter herbivory. J Theor Biol 364: 1-6.

YI B, HU L, MEI W, ZHOU K, WANG H, LUO Y \& DAI H. 2011. Antioxidant phenolic compounds of cassava (Manihot esculenta) from Hainan. Molecules 16: 10157-10167.

\section{How to cite}

SILVA GS, FERRARO A, OGANDO FIB, AGUIAR CL \& APPEZZATO-DA-GLÓRIA B. 2020. Structures related to resprouting potential of two Myrtaceae species from Cerrado: morpho-anatomical and chemical studies. An Acad Bras Cienc 92: e20180472. DOI 10.1590/0001-3765202020180472.

Manuscript received on May 15, 2018; accepted

for publication on November 6, 2018

GABRIELA SANTOS DA SILVA ${ }^{1}$

https://orcid.org/0000-0002-8756-9317

\section{ALEXANDRE FERRARO ${ }^{1}$}

https://orcid.org/0000-0002-3747-4467

FELIPE IWAGAKI BRAGA OGANDO²

https://orcid.org/0000-0002-8030-3022

\section{CLAUDIO LIMA DE AGUIAR ${ }^{2}$}

https://orcid.org/0000-0002-0086-9449

\section{BEATRIZ APPEZZATO-DA-GLÓRIA ${ }^{1}$}

https://orcid.org/0000-0003-2989-6931

${ }^{1}$ Plant Anatomy Laboratory, Luiz de Queiroz College of Agriculture, University of São Paulo, Pádua Dias Avenue, 11, 13418-900 Piracicaba, SP, Brazil

${ }^{2}$ Hugot Sugar Technology Laboratory, Luiz de Queiroz College of Agriculture, University of São Paulo, Pádua Dias Avenue, 11, 13418-900 Piracicaba, SP, Brazil

\section{Correspondence to Beatriz Appezzato-da-Glória} E-mail:bagloria@usp.br

\section{Author contributions}

GSS, BAG and AF performed the anatomical studies; FIBO and CLA performed most of the chemical analyses; all authors actively contributed to manuscript preparation.

\section{(cc) BY}

